\title{
PEMBUATAN BROWNIES DARI UBI JALAR UNGGUDI KELURAHAN TANJUNG KRAMAT KOTA GORONTALO
}

\author{
Making Of Brownies From Purple Road Ubiin Tanjung Kramat, Gorontalo City
}

\author{
Nurhafnita $^{1)}$, , Nur Fitriyanti Bulotio ${ }^{2)}$ Syaiful Umela ${ }^{3}$ \\ ${ }^{1,2,3)}$ Dosen Program Studi Teknologi Hasil Pertanian, Politeknik Gorontalo \\ E-mail : ithawahid@poligon.ac.id ${ }^{1)}$
}

\begin{abstract}
ABSTRAK
Ubi jalar ungu jenis Ipomoea batatas var Ayamurasaki atau sering disebut Ipomoea batatas blackie memiliki warna ungu yang pekat pada dagingnya. Warna ungu yang ada pada ubi jalar ungu disebabkan adanya pigmen ungu antosianin yang ada dibagian daging sampai kulitnya. Ubi jalar ungu cukup melimpah di Indonesia, namun belum secara maksimal dimanfaatkan oleh manusia dalam penganekaragaman makanan. Ubi jalar ungu adalah salah satu komoditas pertanian jenis umbi-umbian yang cukup penting di Indonesia sebagai sumber pangan Oleh karena itu perlu suatu upaya untuk meningkatkan nilai tambah (added value) dari ubi jalar ungu dengan mengolah menjadi beranekaragam produk dan salah satunya adalah brownies ubi jalar ungu.. Brownies kukus merupakan produk yang di hasilkan dari tepung terigu atau jenis tepung lain dengan penambahan bahan-bahan lain untuk menambah zat gizi yang diproses dengan pengukusan atau pengovenan.
\end{abstract}

\section{Kata kunci: ubi jalar Ungu, Brownis}

\begin{abstract}
Purple sweet potato type Ipomoea batatas var Ayamurasaki or often called Ipomoea batatas blackie has a thick purple color on the flesh. The purple color in purple sweet potatoes is due to the presence of anthocyanin purple pigments that are present from the flesh to the skin. Purple sweet potato is quite abundant in Indonesia, but has not been maximally utilized by humans in food diversification. Purple sweet potato is one of the agricultural commodities of tubers that is quite important in Indonesia as a source of food. Therefore, an effort is needed to increase the added value of purple sweet potato by processing it into a variety of products and one of them is sweet potato brownies. Steamed brownies are products that are produced from wheat flour or other types of flour with the addition of other ingredients to add nutrients which are processed by steaming or oven.
\end{abstract}

Key words: Purple sweet potato, Brownis 


\section{PENDAHULUAN}

Ubi jalar ungu cukup melimpah di Indonesia, namun belum secara maksimal dimanfaatkan oleh manusia dalam penganekaragaman makanan. Oleh karena itu perlu suatu upaya untuk meningkatkan nilai tambah (added value) dari ubi jalar ungu dengan mengolah menjadi beranekaragam produk dan salah satunya adalah brownies ubi jalar ungu.Ubi jalar ungu adalah salah satu komoditas pertanian jenis umbi-umbian yang cukup penting di Indonesia sebagai sumber pangan. Ubi jalar ungu jenis Ipomoea batatas var Ayamurasaki atau sering disebut Ipomoea batatas blackie memiliki warna ungu yang pekat pada dagingnya. Warna ungu yang ada pada ubi jalar ungu disebabkan adanya pigmen ungu antosianin yang ada dibagian daging sampai kulitnya (Pokarny dkk, 2001).

Gorontalo Instruksikan Pangan Lokal Jadi Menu Wajib Setiap Kegiatan Pemerintahan. Provinsi Gorontalo menginstruksikan agar setiap Aparatur Sipil lingkungan Pemerintah ataupun masyarakat Gorontalo untuk membudayakan konsumsi panganan lokal dalam setiap kegiatan pemerintahan. Hal tersebut dimaksudkan, selain untuk menjaga kesehatan juga untuk menggairahkan para petani dan pejual panganan daerah. Pemerintah mengaku merasa prihatin, pasalnya selama ini dia menilai aktivitas pemerintahan lebih banyak diwarnai dengan konsumsi buah-buah impor seperti jeruk dan apel.Selain itu, makanan berupa nasi putih yang tinggi karbohidrat dan lauk berkolesterol tinggi, seharusnya segera ditinggalkan dan diganti dengan makanan lokal yang lebih sehat.

Upaya untuk peningkatan petani ubi jalar Gorontalo adalah dengan melakukan inovasi inovasi untuk peningkatan perekonomian petani di gorontaloseperti ubi jalar unggu bisa di aplikasikan menjadi brownis nilai jual yang tinggi.

Jenis ubi jalar ada beberapa macam diantaranya ubi ungu, ubi kuning, ubi putih dan ubi jingga. Karakteristik ubi jalar ungu memiliki warna kulit ungu tua ke hitamhitaman, warna daging ubi ini ungu muda ke ungu tua, memiliki rasa manis tergantung varietasnya. Biasanya semakin lama penyimpanan ubi yang masih mentah maka rasanya akan semakin manis. Salah satu cara untuk memperluas penggunaan ubi jalar ungu adalah dengan cara dijadikan olahan. Kelebihan produk ini adalah tahan lama disimpan, volumenya akan relatif kecil, memudahkan transportasi dan lebih fleksibel sebagai bahan dasar produkproduk olahan ubi jalar ungu.

Keuntungan dari tersedianya ubi jalar ungu tersebut dapat digunakan sebagai bahan subtitusi tepung terigu.Upaya untuk meningkatkan daya guna ubi jalar ungu dan nilai ekonominya dapat dilakukan dengan penganekaragaman pangan dari jenis olahan ubi ungu, untuk itu perlu dikembangkan cara pengolahan lain seperti " Brownies kukus" yang berbahan dasar tepung ubi ungu. Brownies merupakan salah satu jenis cake yang berwarna cokelat kehitaman dengan tekstur sedikit lebih keras dari pada cake karena brownies tidak membutuhkan pengembang atau gluten (Astawan 2009:51). Brownies kukus merupakan produk yang di hasilkan dari tepung terigu atau jenis tepung lain dengan penambahan bahan-bahan lain untuk menambah zat gizi yang diproses dengan pengukusan atau pengovenan (Memil, 2006).

Pemanfaatan tepung ubi jalar ungu pada pembuatan brownies kukus diharapkan dapat meningkatkan nilai gizi dan kesukaan masyarakat terhadap ubi ungu dan meningkatkan nilai ekonomis ubi ungu sehingga ubi ungu tidak hanya dimanfaatkan sebagai pembuatan snack tradisional saja. Tepung ubi ungu dapat digunakan sebagai salah satu alternatif yang digunakan untuk mengurangi terjadinya defisensi vitamin A adalah dengan cara penganekaragaman pangan berbasis pangan lokal sumber vitamin A. Kualitas kue brownies kukus 
ditentukan dari rasa, tekstur, aroma dan tingkat kekerasan. Tingkat kekerasan merupakan suatu faktor ktritis, karena kekerasaan adalah salah satu parameter penting yang berperan terhadap penerimaan konsumen terhadap suatu produk. Faktor yang mempengaruhi tingkat kekerasan pada kue antara lain telur ayam, gula dan pengembang kue dan protein yaitu gluten (Widayati dan Damayanti

Kota Gorontalo memiliki potensi alam yang melimpah karena letaknya di pinggiran pantai, salah satunya adalah kelurahan Tanjung Kramat. Kelurahan ini letaknya sekitar 30 menit dari Kota gorontalo. Kelurahan Tanjung Kramat merupakan salah satu Kelurahan di Kabupaten Gorontalo yang memiliki sumber daya yang bisa dimanfaatkan untuk dijadikan salah satu ukm dengan produk pangan masih kurang. Dengan demikian, perlu dilakukan suatu upaya pihak akademisi yang bersinergi dengan pemerintah untuk memberikan pengetahuan dan keterampilan pembuatan broenis ubi jalar ungu peningkatan. Tim pengabdian Politeknik Gorontalo berinisiatif untuk melakukan sosialisasi dan pelatihan pembuatan Brownies ubi jalar unggu kepada masyarakat setempat.

Tujuannya agar masyarakat dapat mengaplikasikan bahan pangan ubi jalar jadi olahan. Dengan demikian, akan memicu peningkatan pendapatan yang bernilai ekonomis

\section{METODE PELAKSANAAN KEGIATAN}

Pengabdian

Kepada

Masyarakat(PKM) ini dilaksanakan pada bulan Februari tahun 2020 di Kelurahan Tanjung Kramat Kota Gorontalo pada pukul 10.00 WITA sampai selesai Pelaksanaan kegiatan pengabdian dilakukan dalam beberapa tahap yakni:

1) Identifikasi masalah dan cara pemecahannya. Tujuannya untuk mengetahui masalah yang dihadapi oleh masyarakat dalam upaya peningkatan pendapatan masyarakat tanjung karamat.

2) Koordinasi dengan pihak setempat

Rencana kegiatan ini dikoordinasikan kepada semua pihak yang akan dilibatkan terutama pihak pemerintah dan masyarakat Kelurahan Tanjung Kramat. Hal ini agar pelaksanaan kegiatan dapat berjalan sesuai tujuan dan harapan terutama dalam membantu masyarakat

3) Persiapan tim dan teknis pelaksanaan kegiatan.

Tahap persiapan ini dilakukan untuk mempersiapkan kebutuhan utama maupun kebutuhan pendukung kegiatan. Kebutuhan utama seperti materi sosialiasi serta alat bahan pengolahan ubi jalar menjadi produk bernilai ekonomis Sedangkan kebutuhan pendukung seperti absen peserta, konsumsi, dll. Teknis pelaksanaan kegiatan terdiri dari sosialisasi/penyuluhan, praktek dan diskusi

4) Pelaksanaan kegiatan sosialisasi pembuatan broenis ubi jalar unggudimulai dengan penjelasan teori tentang ubi jalardengan menggunakan media penyampaian dalam bentuk powerpoint, praktek pembuatan brownis ubi jalaryang ditunjukkan kepada peserta . Untuk memudahkan duplikasi resep maka tim pengabdian akan membagikan booklet resep pembuatan olahan ubbi jalar ini dalam bentuk softfile ataupun hardfile bersamaan dengan pembagian produk.

5) Diskusi interaktif, dilakukan untuk menjalin tanya jawab dengan peserta dan memberi kesempatan untuk berbagi ilmu dan pengalaman terutama terkait dengan olahan ubi jalar

6) Evaluasi dan pembagian produk ubi jalar Tahap ini dilakukan untuk melihat sejauh mana tujuan tercapai dan manfaat dapat dirasakan oleh semua pihak yang terlibat terkhusus masyarakat Kelurahan Tanjung Kramat sebagai target utama, serta melihat kekurangan selama proses 
pengabdian sehingga menjadi perbaikan ke depan. Selain itu, kegiatan ini diakhiri dengan pembagian produk brownies ubi jalar kepada masyarakat sebagai wujud nyata peran serta dan bentuk kepedulian Kampus Politeknik Gorontalo

\section{HASIL DAN PEMBAHASAN}

Hasil dari kegiatan ini dapat dilihat dari proses dan respon dari masyarakat selama dan setelah kegiatan. Setelah seluruh rangkaian kegiatan PKM ini dilaksanakan, masyarakat Tanjung Kramat akhirnya memiliki pengetahuan tentang olahan ubi jalar.Pengetahuan masyarakat tentangpangan lokal yang biasanya dan umumnya hanyadi panen trus masakan, mereka akhirnya memahami bahwa pangan local ubi jalar ini juga bisa dimanfaatkan sebagai bahan dasar pengolahan kue yang bisa meningkatkan pendapatan masyarakat. Selain pengetahuan, masyarakat Tanjung Kramat juga keterampilan dalam menginovasikan produk lokal menjadi meningkat.

Keterampilan yang diberikan berupa cara mengolah ubi jalar jadi produk ekonomis yang siap dikonsumsi kapan pun, dimana pun dan tahan lama, cara mengolah yang baik dan tepat sehingga gizi dari ubi jalar tidak hilang saat pengolahan serta cara menyimpan agar bertahan lama. Dengan demikian, setelah masyarakat mengikuti kegiatan ini, mereka tidak hanya mengetahui teknik penangangan, pengolahan tetapi teknik mempertahankan mutu dan gizi dari produk olahan tersebut.

Hasil kegiatan pengabdian ini berjalan lacar dan sangat memuaskan. Hal ini terlihat dari sikap penerimaan pihak pemerintah Kelurahan Tanjung Kramat yang sangat terbuka dari awal sampai akhir, antusiasme peserta selama kegiatan, menyimak semua materi yang disampaikan dan interaktif. Proses penyampaian materi juga berjalan lancar.
Selama proses kegiatan berjalan, tim pengabdian tetap menjalankan protokol kesehatan seperti memakai masker, jaga jarak, menggunakan handsanitizer/cuci tangan sebelum/sesudah melakukan kegiatan.

Kekurangan yang dirasakan oleh tim Keterbatasan ruang dan waktu, penyampaian. Oleh sebab itu, tim pengabdi telah menyediakan bahan bahan yang sudah diolah beberapa hari sebelum kegiatan sosialisai di mulai. Agar mitra lebih paham, tim pengabdi memberikan simulasi pembuatan kue broenis ubi jalar dalam bentuk video yang ditampilkan pada saat kegiatan berlangsung.

Kegiatan ini ditutup dengan pembagian produk broewnies ubi jalar kepada masyarakat Tanjung Kramat yang penyerahannya diwakilkan kepada pihak pemerintah dalam hal ini lurah Tanjung Kramat. Berikut gambar kegiatan pengabdian oleh tim :

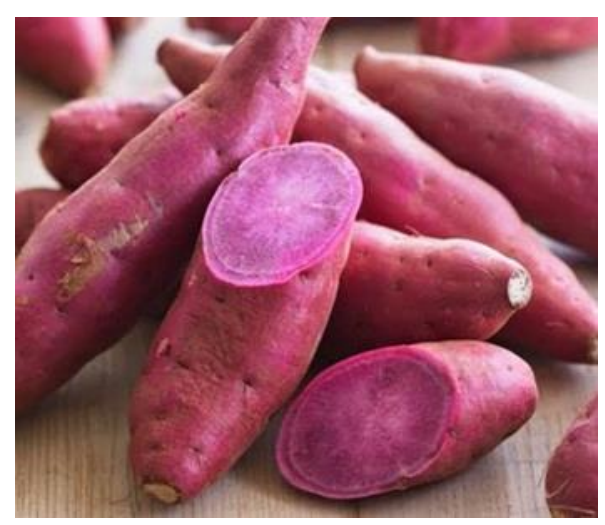

Gambar 1. Produk utama olahan 


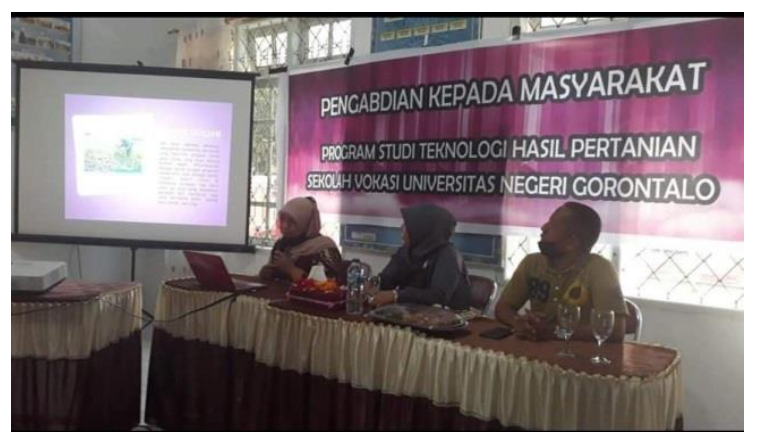

Gambar 2. Proses Pemaparan materi sosialisasi dan pengolahan produk brownis ubi ungu

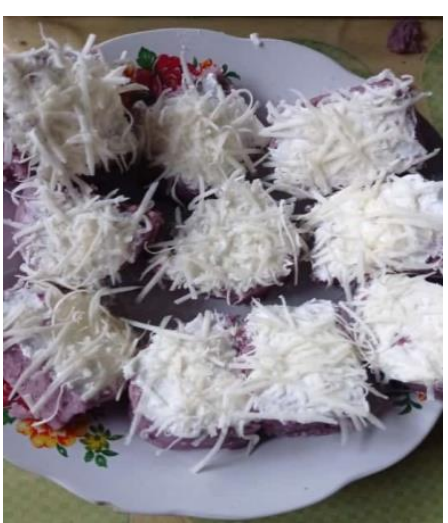

Gambar 3. Produk olahan Brownis Ubi Ungu

\section{KESIMPULAN}

Kesimpulan pada kegiatan pengabdian ini antara lain tercapainya kerjasama yang sinergis antara pemerintah, akademisi, dan masyarakat menciptakan keterampilan dan pengetahuan masyarakat agar dapat menginovasi produk lokal agar lebih meningkat

\section{DAFTAR PUSTAKA}

Astawan.2005. Ahli Teknologi Pangan dan Gizi. Institude Pertanian Bogor IPB..Akses : 20 April 2020.

Pokorny, J., N. Yanishleva, and M. Gordon. 2001. Antioxidant in Food. Woodhead Publishing Ltd. EnglandAkses : 20 April
Memil, KH. 2006. Pemanfaatan Singkong sebagai Bahan Baku Bolu. Tugas Akhir. Fakultas Teknik, UNNES. Semarang.

Soewitomo Sisca, 2013, 50 Resep Step By Step Kue \& Cake Manis, Gramedia Pustaka Utama, Jakarta. 